\title{
Ireine's Education Model to Improve Tooth Brushing Skills in Preschool Children
}

\author{
Ireine Norma Dajoh ${ }^{1}$, Bedjo Santoso ${ }^{2}$, Lanny Sunarjo ${ }^{3}$, Ari Suwondo ${ }^{4}$, Waljuni A.Rahman ${ }^{5}$, Diyah Fatmasari ${ }^{6}$

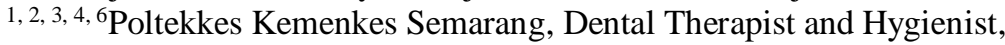 \\ Tirto Agung Rd., Semarang, Central Java, 50268, Indonesia
}

${ }^{5}$ Poltekkes Kemenkes Banjarmasin, Dental Therapist and Hygienist, H Mistar Cokrokusumo Rd., Banjar Baru, South Kalimantan, 70714, Indonesia

\begin{abstract}
Dental and oral health problems in preschool children i.e. Early Chilhood Caries (ECC) is amounted to $90.05 \%$. This is because the children have not been able to do the tooth brushing activities on their own. The modified Ireine's Education Model reflects a model of change in dental hygiene behavior of preschool children in the habit of tooth brushing from an early age. Its aim is to improve the tooth brushing skills of preschool children with guidance from their teachers and parents. The aim of generating modified Ireine's Education Model is as an effort to improve the tooth brushing skills of preschool children. The study method Research and Development (R \& D) with Quasy experiment. The subjects of the preschool children were divided into 2 groups: Intervention group with the modified Ireine's Education Model which was done for 21 days and control group with Phantom Media. The independent variable in this research is the modified Ireine's Education Model, while the dependent varibale is tooth brushing skills in preschool children. The data was tested using Intraclass corelation test coefficient, Anova, Shapiro Wilk, Wilcoxon, and Mann Whitney. The result indicates that the modified Ireine's Education Model is more effective raises the free score of preschool children plaque with $p$-value in less than 0.001. Furthermore, it improves their tooth brushing skills with p-value in less than 0.010 compared to the control group. In conclusion, the modified Ireine's Education Model is more effectively improves the skills of brushing in preschool children as opposed to phantom media.
\end{abstract}

Keywords:- Preschool Children, Modified Ireine's Education Model, Tooth Brushing Skills

\section{INTRODUCTION}

Caries that often occurs in preschool children called Early Childhood Caries (ECC), is a hard tooth tissue disorder that attacks deciduous teeth in preschool age[1]. The impact of caries, which is more than 50 million hours per year lost due to children cannot attending school, will affect intellectual performance and decrease children's performance[2]. According to World Health Organization (WHO), as much as $90 \%$ of children experience caries, while the prevalence of ECC in children aged 5-6 in Indonesia is $90.05 \%$. This figure is still far from expectation when compared with the World Health Organization
(WHO) target that sets the 2020 DMF-T value for children is 1 and Indonesia free of caries by 2030[3].

The cause of high dental and oral hygiene problems in preschool children is the poor care of dental and oral hygiene behavior. Behavior has an influence of $30 \%-35 \%$ on health status. The behavior in protecting dental and oral health affects one's actions to take care their dental and oral health. Therefore, an effort to shape behavior from an early age is necessary. Effort to change the behavior of protecting dental and oral hygiene is through dental and oral health education performing training method for teachers and parents to direct the children to the habit of brushing their teeth properly, because children have not been able to do the brushing activities on their own. Assistance of teachers and parents is important to guide the children so that they can carry on brushing their teeth properly. Children are guided to be able to apply it individually and routinely so that they are accustomed to healthy and clean living behavior[4][5].

Children's behavior towards protecting dental and oral health is influenced by the behavior of parents. Hence, the role of parents is needed to provide understanding and remind children to take care of their dental and oral hygiene.[6] Parents have responsibilities in good oral health behavior in children including educating and supervising brushing teeth, and doing dental care.[7] Teachers and parents are the best promoters at school or at home because they have the capability and capacity to educate, guide, and train children. Besides, they play a role in inviting and providing dental and oral health education so that children are more motivated to carry out the activities taught[8]. The change of person's behavior depends on the stimulus provided, meaning that stimulus which matches the characteristics of preschool children will help with the stages of behavior change.[9]

According to behavior change theory ( Maher C.A, 2014), is that to change a person's habit, it requires a constant period for 21 days at minimum. This theory consists of three stages, namely: First, Introduction / introduction (first 7 days). At this stage, children are invited to get to know the form of activities in a fun way. Second, repetition / exercise (second 7 days), at this stage the children will make repetitive movements and, third, Strengthening (last 7 days). The third seven days are more towards strengthening towards consistency. During this period, it is expected that the behavior will have formed 
permanently into a habit. Furthermore, it is also expected that the behavior will have formed permanently into a habit. Tooth brushing activities done repeatedly with direct pratice will make it easer for children to apply the message be delivered. [10] Consistency is needed to achieve behavioral change. The more often children do these activities, the more easily they memorize and enjoy. This behavior change theory is suitable to be applied in preschool children, because children are in golden age period, with respect to human development such as physical, emotional and social. At this occasion, the child experiences an increase in intelligence.[11]

At this age, it is an ideal time to practice motor skills including tooth brushing. When children are brushing their teeth according to the stages above and over again for 21 days constantly, there will be changes in the behavior of protecting dental and oral health so that they can improve good tooth brushing skills. However, this theory does not explain the role of teachers and parents on changes in children's behavior. [12] Therefore, it is necessary to make an effort to improve the behavior of correct toothbrushing through innovative development of a toothbrushing program in preschool children with "Modified Ireine's Education Model" which is a model of behavior change dental and oral health of preschool children in getting used to brushing their teeth from an early age with the purpose of improving their tooth brushing skills done in the morning after breakfast and at night before going to bed by using learning media as a stimulus and involving the participation of teachers and parents so that children can performed what was delivered. This model has 4 stages: training, simulation, practice and evaluation combined with media of story telling, role playing and video.

\section{METHODOLOGY}

We have implemented Research and Development ( $R$ \& D) method for this research which has aim to develop a model of teaching and learning of dental and oral hygiene of preschool children. The Research and Development (R\&D) method is a research method used to produce product and test the effectivity of the product. The procedures of R\&D comprises five stages, i.e. Information collection, design and build of model, validation from expert and revision, model testing, and model results[13]. The research design used quasy experiment. (pre and post-test with control group design).

This research took place at the Tunas Bhakti Kindergarten Semarang, Indonesia as an intervention group and Al Ijabah Islamic Kindergarten Semarang as a control group. The sampling technique was purposive sampling totaling 40 children who were divided into two groups: an intervention group of 20 children and remaining 20 children as control group. Data on the measurement of tooth brushing skills and plaque-free scores were performed with a statistical test. The research data used a ratio scale so that the normality test then using the Shapiro Wilk. Statistical test to analyze the variable data in the normal data paired group used the dependent sample test and the non-paired group used the independent sample test. In the abnormal data, the paired group used the Wilcoxon test and the nonpaired group used the Mann-Whitney test.

\section{RESULTS AND DISCUSSION}

\section{A. Data Collection}

The results of data collection conducted through interview method and Systematica Literature Review concluded that to improve preschool children' tooth brushing skills, the learning and media method are necessary, fit to the characteristics of preschool children, such as a pleasant atmosphere so that children easily understand and do what was taught.

\section{B. Design and Build}

The design was made based on data from the results of data collection, which revealed that preschool children were not yet able to perform self-care in carrying out the practice of tooth brushing. Thus, we made a Modified Ireine Education Model that was adapted to the needs of learning method and media that fit the characteristics of preschool children.

\section{Expert Validation}

Table 1 shows the results of validation from the expert. It shows that p-value is 0.006 , which is less than 0.05 , meaning that the Modified Ireine's Education Model is relevant as the dental and oral hygiene education in preschool children.

\begin{tabular}{|c|c|c|c|}
\hline \multicolumn{4}{|c|}{ Expert Validation } \\
\hline & $\mathbf{n}$ & $\mathbf{f}(\%)$ & $\boldsymbol{p}$-value \\
\hline Relevant & 10 & 100 & 0,000 \\
\hline Irrelevant & 0 & 0 & \\
\hline
\end{tabular}

* Intraclass correlation coefficient

Table 1:- Expert Validation

\section{Model Testing}

Table 2 shows the normality test results. It shows that the normality test in preschool children obtain p-value less than 0.05 , so that the data distribution is not normal. Thus, it could be continued using non-parametric test.

\begin{tabular}{|c|c|c|}
\hline \multirow{2}{*}{ Variable } & \multicolumn{2}{|c|}{$\mathrm{p}$-value } \\
\cline { 2 - 3 } & Intervention & Control \\
\hline & 0.009 & 0.001 \\
\hline Pre-test skill & 0.000 & 0.013 \\
\hline Post-test skill & 0.029 & 0.039 \\
\hline $\begin{array}{c}\text { Pre-test plaque } \\
\text { index }\end{array}$ & 0.042 & 0.004 \\
\hline $\begin{array}{c}\text { Post-test plaque } \\
\text { index }\end{array}$ & *Shapiro-wilk \\
\hline \multicolumn{2}{|c|}{} \\
\hline
\end{tabular}

Table 2:- Normality Test 
Table 3 shows the paired-data effectivity test. It shows that the $p$-value of the intervention group is 0.000 ( $p$ $<0.05$ ), meaning that the Modified Ireine's Education Model effectively improves the child's brushing skills. The $\mathrm{p}$-value of the control group is $0.000(\mathrm{p}<0.05)$ meaning that the phantom media is effective in increasing preschool children's toothbrushing skills.

The effectivity test of the children's plaque-free score data show that the p-value of the intervention group is 0.000 ( $\mathrm{p}<0.05)$ meaning that the Modified Ireine's Education Model effectively increases the child's plaquefree score. The $\mathrm{p}$-value of the control group was 0.000 ( $\mathrm{p}$ $<0.05$ ) indicating the phantom media is effective in increasing the child's plaque-free score

\begin{tabular}{|c|c|c|c|c|c|}
\hline Variable & & \multicolumn{4}{|c|}{ Paired-data test } \\
\hline & & $\mathrm{n}$ & Mean \pm SD & Delta & Pvalue \\
\hline \multirow{2}{*}{\multicolumn{6}{|c|}{ Skill }} \\
\hline & & & & & \\
\hline Intervention & pre & 20 & $6,95 \pm 1.191$ & \multirow[t]{2}{*}{2,25} & \multirow[t]{2}{*}{0.000} \\
\hline & Post & 20 & $9,20 \pm 0.834$ & & \\
\hline Control & pre & 20 & $7,00 \pm 1.170$ & \multirow{2}{*}{1,90} & \multirow{2}{*}{0.000} \\
\hline & post & 20 & $8,90 \pm 0.986$ & & \\
\hline \multicolumn{6}{|l|}{$\begin{array}{c}\text { Plaque-free } \\
\text { score }\end{array}$} \\
\hline Intervention & pre & 20 & $49,15 \pm 4.157$ & \multirow[t]{2}{*}{40,90} & \multirow[t]{2}{*}{0.000} \\
\hline & post & 20 & $90,05 \pm 5.404$ & & \\
\hline Control & pre & 20 & $47,16 \pm 5.028$ & 37,4 & 0.000 \\
\hline
\end{tabular}

*wilcoxon test

Table 3:- Paired-Data Effectivity Test

Table 4 shows the non-paired data test on its effectivity. The information obtained from the table is that the $\mathrm{p}$-value is 0.001 ( $\mathrm{p}<0.05)$, meaning that the Modified Ireine's Education Model is more effective in improving children's tooth brushing skills compared to phantom media. The effectiveness test of the children's plaque-free score data shows that the p-value is 0.010 ( $p<0.05)$ meaning that the Modified Ireine's Education is more effective than that with Phantom.

\begin{tabular}{|c|c|c|c|c|c|}
\hline Variable & \multicolumn{5}{|c|}{ Non-paired data effectivity test* } \\
\hline & $\mathrm{n}$ & Mean & Delta & SD & Pvalue \\
\hline Skill & & & & & \\
\hline Intervention & 20 & 9,20 & 0,30 & \multirow{2}{*}{0,900} & 0.001 \\
\hline Control & 20 & 8,90 & & & \\
\hline Plaque-free score & & & & & \\
\hline Intervention & 20 & 90,05 & 5,49 & \multirow{2}{*}{5,362} & 0.010 \\
\hline Control & 20 & 84,56 & & & \\
\hline
\end{tabular}

*mann whitney

Table 4:- Non-Paired Data Effectivity Test

\section{E. Model Results}

The results of the model in the form of a story book shown in Figure 1 is with toothbrushing content, becoming the output of the development of learning method and media for dental and oral hygiene of preschool children.

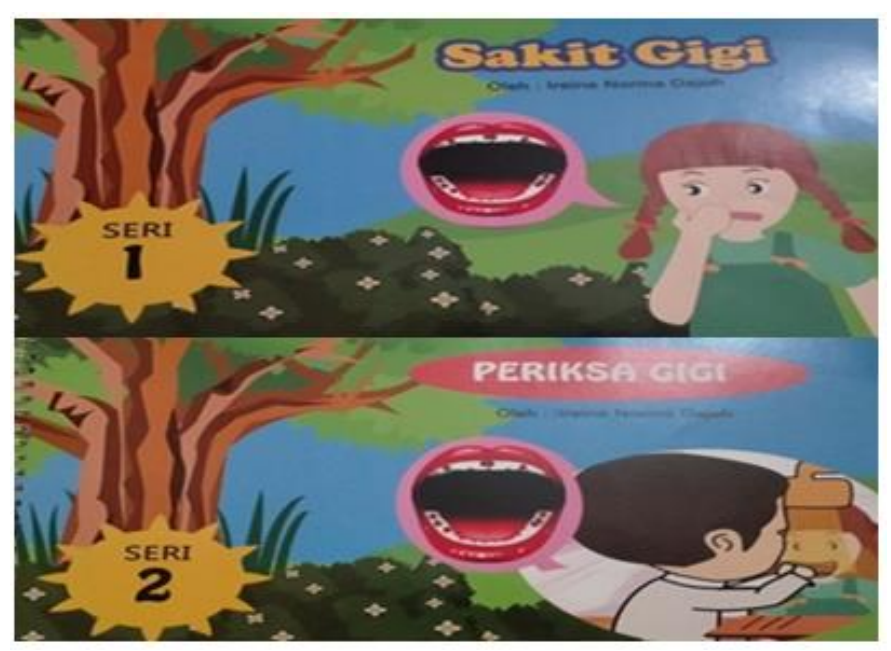

Fig 1:- Story book

\section{DISCUSSION}

The results of the data collection inferred that to improve the skills of tooth brushing in preschool children, it requires an effort in dental and oral hygiene education by providing suitable learning method and certainly supported by learning media which can impress the children, so that children can get the information and have the ability to implement what has been previously taught. The purpose of the learning media is as a learning aid to facilitate the learning process in the classroom, increase the efficiency of the learning process, and help students concentrate in the learning process. Tooth brushing learning model suitable to achieve this purpose is the Modified Ireine's Education Model.[14]

Design and build of The Modified Ireine's Education Model is created based on the results of data information that suits the needs of the model and learning media of preschool children. The results of data collection revealed that preschool children can't do self-care yet in carrying out the practice of tooth brushing, so it is necessary to involve the role of teachers and persons to guide them in the implementation of tooth brushing. Teachers and parents play an important role in improving children's dental and oral hygiene by accompanying and guiding the children so that they are able to brush their teeth properly and implement it in daily life especially in the morning after breakfast and at night before going to sleep. Teachers and parents are the best promoters either at school or home because they have the ability to guide and provide dental and oral health education so that children are more motivated to carry out activities have been taught. [5][8] Dental and oral health education intervention can be given by teachers and parents to preschool children. Somehow in the process, teachers and parents need to be trained first because with the knowledge, attitudes and actions to 
preserve or protect dental and oral hygiene, the teachers are able to transfer the knowledge and skills. In accordance with the research of Gao et al. (2013) the model of promoting dental and oral hygiene to preschool children should emphasize promotive and preventive involvement by taking the role of parents / teachers in the implementation.[15]

Expert validation results show that The Modified Ireine's Education Model reaches 90\% relevant for the learning media in preschool children. This relevance causes preschool students to perform this model well. The validation process needs to be carried out in order to produce a useful learning model to improve the quality of education.[16] The Modified Ireine's Education Model was applied to preschool children to improve their brushing skills and plaque-free scores. Tooth brushing skills in preschool children have increased because they were given simulations using story telling media, role playing and video, as well as practical brushing method for 21 days. Using various method and learning media can improve the skills of preschool children. The practice of brushing teeth was done for 21 days, carried out at school in the morning after a break accompanied by the teacher and carried out at home in the morning after breakfast and at night before going to bed accompanied by parents. This is in line with the theory of behavior change which says that changing one's habits requires a constant period.[17]

The implementation stage of The Modified Ireine's Education Model to preschool children was done by providing simulations on how to brush their teeth properly and correctly by the teacher. Learning with simulation method is an effective means of increasing children's knowledge, motivation, activeness, confidence and creativity in the learning process[18][19]. This simulation is supported by story telling, role playing and dental and oral hygiene videos. The response of children was that children quickly understand what had been taught so that they were more motivated to do the lesson. Preschool children's plaque-free scores have improved because preschool children got correct and proper tooth brushing practices for 21 days. Practice is an action that arises as a result of a stimulus has been given previously or the most effective way of completing tasks based on procedures have been delivered beforehand[20]. When children can peform tooth brushing correctly and properly, it will improve their dental and oral hygiene.[21][22] The Modified Ireine's Education Model is said to be successful because the children were able to perform proper and correct tooth brushing skills which is in consequent, it increases their plaque-free scores. The success of Modified Ireine's Education Model is due to the strengths of this model, which is not only the constant implementation of 21 days, more stimulus in the learning process and involves the participation of teachers and parents in guiding and assisting children to brush their teeth at home in the morning after breakfast and at night the day before going to bed, but also brushing at school after meal can improve the tooth burushing skills of preschool children.

\section{CONCLUSION}

As preschool children are prone to dental and oral health problem, thus it is necessary to put in a method to raise the awareness of preschool children to tooth brushing. This research used Modified Ireine's Education Model. Based on the results of the research, it can be concluded that the Modified Ireine's Education Model has been proven to be more effective in increasing the teeth brushing skills of preschool children.

\section{REFERENCES}

[1]. E. A. Kidd and S. J. Bechal, "Basics of Caries, Causes and Treatment," 1987, Terjem. N. Sumawinata dari Essentials Dent. Caries, Dis. Its Manag., pp. 99-100.

[2]. B. Santoso, E. Ningtyas, E. Aryati, and D. Fatmasari, “Improving Elderly's Dental Hygiene Through Nursing Home Staff's Dental Health Education at the ," 2017 KEMAS J. Kesehat. Masy., vol. 12, no. 2, pp. 189-198.

[3]. R. Z. Taftazani, L. Rismayani, B. Santoso, and T. Wiyatini, "Analysis of UKGS program in Puskesmas Halmahera," 2015 J. Kesehat. Gigi, vol. 2, no. 1, pp. 25-31.

[4]. R. Hasbullah and E. Sulaeman, "Fostering Student Entrepreneurial Character through Softskills Training Methods at the Faculty of Economic Uniska," $2012 \mathrm{~J}$. Manaj., vol. 9, no. 2, pp. 559-576.

[5]. N. Aisyah, D. K. P. U. I. N. S. Kalijaga, and U. M. S. S. S. Guna, "Teacher's Efforts in Developing Children's Oral Language Creativity Through the Role Playing Method and Storytelling Method Di Tk Bhayangkari 23 Bandar Lampung 2017," 2017, Darul Ilmi : Junal Ilmiah Pendidikan Guru Raudhatul Afthal, $1(1), 8-33$

[6]. L. Sunarjo, E. Mardiati, and N. F. Miftakhun, "External Factors Causing Dental Caries in PreSchool Children PAUD Strowberry RW 03 Kelurahan Bangentayu Wetan Kota Semarang 2016, 2016, Jurnal Kesehatan Gigi, vol. 3 no. 2.

[7]. N. Widyastuti, D. Fatmasari, and M. Djamil, "The Effectiveness of Heni's Dental Flannel Book" on Increasing Dental Health Care Among Early Childhood Education Program.," 2020, J. Appl. Heal. Manag. Technol., vol. 2, no. 2, pp. 34-41.

[8]. A. Riolina, "the role of the teacher in improving dental and oral health of students in elementary school," 2018, JIKG (Jurnal Ilmu Kedokt. Gigi), vol. 1, no. 2, pp. 51-54.

[9]. D. R. Sari, I. M. Ramdan, and F. R. Hidayat, "Comparison of the Effects of Health Education on How to Brush Teeth Between Simulation Methods and Watching Videos on Tooth Brushing Skills in Students TK B di TK It As-Salam Kecamatan Palaran, Kota Samarinda," 2015, Digital Repository Universitas Muhamadyah Kalimantan Timur .

[10]. D. Fatmasari, R. Rasipin, B. Santoso, S. Supriyana, and W. J. D. Utami, "MOGIGU (Menggosok Gigi Asyik Dengan Lagu) To Increase Brushing Teeth Of The Elemtary School," J. Appl. Heal. Manag. 
Technol., vol. 1, no. 1, pp. 16-22, 2019.

[11]. C. A. Maher, L. K. Lewis, K. Ferrar, S. Marshall, I. De Bourdeaudhuij, and C. Vandelanotte, "Are health behavior change interventions that use online social networks effective? A systematic review," 2014, J. Med. Internet Res., vol. 16, no. 2, p. e40.

[12]. W. Martani, "Method of stimulation and emotional development of early childhood ," 2012, J. Psikol., vol. 39, no. 1, pp. 112-120.

[13]. S. Tarsito, "Quantitative, Qualitative and R\&D Research Methods," 2014, Alf. Bandung.

[14]. S. Astutik and B. K. Prahani, "The Practicality and Effectiveness of Collaborative Creativity Learning (CCL) Model by Using PhET Simulation to Increase Students' Scientific Creativity.," 2018, Int. J. Instr., vol. 11 , no. 4, pp. 409-424.

[15]. X. Gao, E. C. M. Lo, C. McGrath, and S. M. Y. Ho, "Innovative interventions to promote positive dental health behaviors and prevent dental caries in preschool children: study protocol for a randomized controlled trial," 2013, Trials, vol. 14, no. 1, p. 118.

[16]. H. Setiawan, S. Adi, and N. H. Ulfah, "Development of Interactive Multimedia Based on Autoplay as a Health Promotion Media About Dental and Mouth Health in Grade V Students of Malang, SDN Percobaan 02 Kota Malang," 2017, Prev. Indones. J. Public Heal., vol. 2, no. 2, pp. 93-103.

[17]. M. Kahana and J. Junaidi, "The Effect of Application of the Consideration Model on the Formation of Student Attitudes in Sociology Learning in Class XI IPS of Adabiah Padang High School, Kelas XI IPS SMA Adabiah Padang," 2019, SOCIUS, vol. 6, no. 2, pp. 62-69.

[18]. S. Hastuti and A. Andriyani, "P Difference in Effect Dental Health Education in Increasing Knowledge about Dental Health in Children SD Negeri 2 Sambi Kecamatan Sambi Kabupaten Boyolali," 2010, Gaster J. Kesehat., vol. 7, no. 2, pp. 624-632.

[19]. W. Ningrum, "Effect of Education and Training on Employee Performance (Study of PertaminaPertoChina East Java Joint Operating Body Employees)," 2013, J. Adm. Bisnis, vol. 6, no. 2.

[20]. R. Rumidjan, S. Sumanto, S. Sukamti, and S. Sugiharti, "Training in making learning media to improve the quality of learning for elementary school teacher," 2017, Abdimas Pedagog. J. Ilm. Pengabdi. Kpd. Masy., vol. 1, no. 1.

[21]. R. N. M. Lila and M. A. Sodik, "Risk Factors Of Dental Career Events In Pres School Children Ra AlHakim Village Damage Subscription Kesamben Blitar District," 2019, J. Glob. Res. Public Heal., vol. 4, no. 2, pp. 105-112.

[22]. S. Petrauskienė, J. Narbutaitè, A. Petrauskienè, and J. I. Virtanen, "Oral health behaviour, attitude towards, and knowledge of dental caries among mothers of 0-to 3-year-old children living in Kaunas, Lithuania," 2020, Clin. Exp. Dent. Res., vol. 6, no. 2, pp. 215224. 